\title{
The sacramental character of man and of creation
}

\author{
PhD. Mihai Sebastian STOIAN \\ Ovidius University of Constanta \\ ROMANIA \\ E-mail: stoian.mihai55@yahoo.com
}

\begin{abstract}
God made Himself a man for man to reach the likeness of God - this is the essential idea of the oikonomia of our salvation, dear to all the Church Fathers, from Saint Irenaeus to Saint Athanasius the Great and the essence of Christ, mystery and original and fundamental sacrament of our meeting with God and of our salvation, of all of us, in Christ, and of the acquisition by each man of the fruits of salvation and deification through Christ, in the Holy Spirit, in His Church. Christ's mystery and sacrament begins by the Embodiment of the Father's Logos. The Passions, the cross, the tomb and the resurrection are its continuation. And all these translate the mystery of the reason why God created everything and the very mystery of man participating to the original mystery, namely Christ, and the Church, as sacrament. Therefore, Christ is the Mystery and the sacrament by excellence original and general -, spring and content of all the mysteries and sacraments, condition and explanation of all these.
\end{abstract}

Keywords: Sacrament, Logos, Creator, embodiment, image, man.

\section{Introduction}

The creation is a free act of the will and not a natural overflow as the irradiation of the divine energies, is the work of a personal God, of the Trinity that has a common will that belongs to the nature of God and which works according to the decision of God's thinking, this is what is called: "The eternal and unchangeable Saint of God" [1]. The creation is a free act of His will and this is the only ground of the beings.

Any creature has its point of contact with the divinity; everything is contained in the Logos. The Logos, God the Word, Who appears as a divine centre from Whom the creating rays emerge, particular logoi (reasons) of the beings, a centre towards Whom the created beings tend, in their turn, as towards their ultimate target. Created to be deified, the world is dynamic, tending towards its ultimate target, determined previously in the ideas-wills. The latter have their centre in the Logos, hypostatic wisdom of the Father, Who manifests Himself in everything and Who brings everything in the Holy Spirit to the union with God. In God there is nothing to cease, nothing to have an end. The Word of God is born, but does not pass. God did not create for a certain time, but for eternity; He brought the being into existence by His creative Word: "because everything that was created by God in the various natures comes together in man as in a melting pot, to form in him a matchless perfection, as a harmony composed of different sounds". Therefore, man was finally created to be introduced in the universe as a king in his palace, "as a prophet and as a priest". The world was made out of nothing only by God's will, this is its origin. The world was created in order to participate to the fullness of the divine life, this being its calling. It is called to make this 
freedom perfect in union, in free agreement of the created wills with the uncreated will of God.

\section{The grounds of man's mystery.}

An important aspect of the cosmology is the creation of man in the image of God. While the whole relation of the creation, with the evident veiled implications of a Christological discourse, becomes deeply logosic in the light of the New Testament, the interpretation of the term image of God, in the light of Pauline theology, acquires profoundly Christological meanings: "For the Holy Apostle Paul, "Image (eikon) of the unseen God" (Colossians 1:15) is Christ. And man is, as we will see, an image of the Image (eikon eikonos). But also the Christological term met in Saint John "word (logos) of God" has, as we know, a close, if not identical content as significance with the Pauline term: "Image of the unseen God" [2].

Christ represents, therefore, the Archetype and the Telos of the human existence: "Saint Irenaeus of Lyon says that "The historical Christ was the Prototype that God had in mind when He created the first man, who was to appear on earth. The Creator foresaw and created Adam according to this future Prototype. Consequently, Adam was created in the image of the Word, Who was to assume in time, as Christ, the human nature, and show Himself as a perfect man on earth" [3]. It is understandable that man does not find the archetypal structure of his creation only in the deified humanity of Christ, but in the Logos of God Himself, and, finally, even this humanity is deified by the Logos according to the model contained in Himself.

The statement that man is the most complex being is justified. No matter how many books we were to write on him, one cannot exhaust the content of man's mystery. This happens because man is the image of God, and his mystery is eternally related to the mystery of Christ. Man was created according to the model of the Logos, for the created being to correspond with God. Certainly, in the eternal plan of God there was also the possibility of the Embodiment since the eternity, but the One through Whom man was created, according to the divine plan, namely the divine Logos, is the One Who makes Himself a man, so that His work may be accomplishable precisely since it belongs to Him as to the One Who has put His seal on it. He was the Model of the created being. So, God's Son created man out of love, able of love and of dialogue with his fellows and with the Trinitarian Persons, possessing, inscribed in his psycho-physical constitution, his adaptability to the divine and a capacity of receiving the divine message. God made man, since the beginning, related to Himself. God's Son did not assume anything else except the human nature that He Himself had created, together with the soul [4].

The Logos is the actual centre of the world and the grounds over which all the created things are placed. By virtue of his special relation with the Logos, man is not a secondary centre of the creation, because everything was created for man and ordained according to man's destiny.

To support the idea that man occupies a central place in the world, Saint Maximus the Confessor developed a whole theology. Man has a central place to the extent to which he preserves the communion with the divine Logos and manifests himself as another logos, as a factor of activation of the world's rationality. Saint Maximus shows that man holds, physically, by the property of being in relation with all the aspects of the reality, the power to unify all the dimensions of the world. Man's calling is to be an active factor of the harmonious union of all the beings, guiding them towards God and bringing them together in Him [5]. 
Regarding man's relation with the world, although it manifests itself by means of the body, however the body appears as an entity of an infinitely complex sensitivity, due to the soul. It is in the soul that man perceives all the vibration of the world, and it is also through it that the complex relation of the human person with the world is expressed [6]. For this reason, the mystics of the Christian East, from Macary the Egyptian to Seraphim of Sarov, affirmed that the communion with God is realized by the human being as a whole and that the divine light can irradiate from the body of the deified man [7].

The Orthodox theology does not know the opposition between created and uncreated, between matter and grace and, for this reason, according to it, grace penetrates in the materiality of the human body; moreover, it claims that "only the whole man can receive grace and not one or the other of the components of the human complex: his imagination, his soul, his body, taken separately [8]. If the body is penetrated - as the whole world matter by the uncreated divine energies by which God is present in every little part of the universe as a deifying, transforming and preserving power, if God is not excluded and considered absent from the creation, it is only in this way that we can have a theological perspective on the creation, a perspective permitting us to see in the creation the gift of God and to perceive it as a means of sanctification and salvation for man.

Not just the soul, but also the human body participates to the character of image, namely man in the entirety of his being is "in the image of God". In this sense, Saint Gregory Palamas underlines: "The name of man is not applied to the soul or to the body separately, but to both of them together, because together they were created in God's image" [9]. Maybe out of the same reasons, namely the intimate union between body and soul, Tertullian and the Blessed Augustine could see the image of God in man, the man's likeness with God, precisely in man's body [10]. According to the divine Revelation, Christ is not just a Redeeming God, as some Christian confessions teach, but is also the Pantocrator, the Holder of everything in the universe, present and active by the internal rationality of the cosmos [11]. And the embodied Logos is Christ. It is dignified and adequate for God's Son to take on a human body, because it has been created by Him, and man is made up of body and soul, therefore he has carried the image of the Logos.

The relation between creation and salvation is expressed the most briefly and clearly by Saint John the Evangelist, saying about God that "He came to that which was His own" (John 1:11). Commenting on this syntagm, Father Stăniloae observes that there are two meanings in it: 1) "His own" are created and supported by Him or through Him; 2) "He came to that which was His own" means that He took on our human nature. But this means as Father Stăniloae says - that "he had something in Him close to our own, a fact shown in our being created "in His image"... He is, in a way, our model or our prototype" [12]. Understanding and accepting this relation between the Logos and the creation is capitally important for the world's destiny.

\section{The significance of the Logos for man}

"Everything is contained in the Logos, the Second Person of the Holy Trinity, Who is the first principle and the ultimate target of all the things created". So, any creature has its contact point with the Divinity: this is its idea, its reason, its Logos, Who is at the same time the target to which he tends. The ideas of the individual things are contained in higher and more general ideas, as species are in genres" [13].

Man, as a created element, can find again his origin only in the Logos: "In a special way, He is the Prototype of man, who is in essence the words that express him and all the 
things he is connected with, as things that come, too, from the Supreme Word. The Word, creator and holder, has in Himself the words or the reasons of all, of some as subjects of words, of others as their content, different from the content of the persons subjects of the words, but meant to become theirs".

The creation of man in the image of God is reflected in man's features. Thus, if this image of God is identified with the Logos, and the Logos is thought of as a Person, it is necessary for man to be a person, too - a subject of communion: "The human subject is the thinking personal reason, created in a correspondence with the things thought by the Divine Logos before creating men. The Logos does not create just subjects brought into existence according to His Image, but subjects meant for a dialogue with Him."

At the same time, if the Logos is conceived as a Person hypostatizing a being, then man, too, must respect the same structure. For this reason, "Man is at the same time the person and the nature or, more precisely, the person concretizing and revealing the nature, because he is an Image of the Son, representing a distinct personal hypostasis of the Unique and Indivisible Being, common to the Father, to the Son and to the Holy Spirit." [14].

Man conforms to his Archetype not just on the level of His ontological structure, but also in point of mirroring His essence (not of reproducing Him). Thus, a man created in the image of Reason must necessarily be rational and is called to partake in this Reason: "Since he represents an image of the Creator's all-wisdom, man's wisdom (sophia) has the power and the duty to ascend to all-wisdom, as well. Saint Athanasius the Great says: "But in order for the creatures not just to exist, but also to exist in Himself, it pleased God to let His Wisdom descend to the creatures, to settle a certain impression and a seal of His Image in everything, for those that were made to show themselves wise and worthy of God. Just as our word is an image of the Word who is God's Son, so is His wisdom, in which (created wisdom), having the possibility of knowing and thinking, we make ourselves receivers of the Creating wisdom. Man is understood by the Holy Fathers ontologically only as a theological being. His ontology is Johanneic". Man's rationality can be found both on the level of his capacity of thinking, and on the level of his potentiality of being a speaking being: "It would be correct to understand that man is a reasonable-speaking being, because he was created in the image of Christ, Who is the Reason - the Hypostatic Word of the Father. Saint Athanasius the Great, who ponders over this theme, in particular, formulates it clearly: "After His own Image He made them, also giving them the power of His Word-Reason; so that, having it in them a sort of outline of the Word-Reason and making themselves rational, they may be able to remain in happiness".

As a person created after the model of the Logos, man represents a subject of communion, who can enter a dialogical relation with God, and as a rational person, he can collaborate with the Divinity: "In this way, we can understand that man is a creator (demiourgos) because he is the Image of the Word-Reason, creator by excellence: "And in this concern, man is made an image of God, because as a man he collaborates (sinergoi) to the making of man" (cf. Clement of Alexandria). "Consequently, it becomes clear that the essence of man is not to be found in the matter out of which he was created, but in the Archetype (model) based on which he was conceived and to which he tends. As the truth of the icon is to be found in the person depicted in it, similarly the truth of man is to be found in his Model" [15].

The Logos or the Word Himself made Himself a man to change and bring back to Him the human nation. Man is therefore a rational Being, made up of soul and body; he is the union and the unity of these two. God called the whole man, not just a part of him, to life 
and to resurrection. In the Book of Genesis 1:26: "Then God said: "Let us make man in Our image, after Our likeness" [16], the use of certain images and symbols to express this truth of faith is determined by the need of human expression and understanding.

Man possesses, by his very nature, the reason of attaining the truth. Only the Logos, the supreme Reason, could have protected man, His most qualified representative in the middle of nature. The contribution of the Logos is made visible especially in the creation of reason: "which is light to the mind and ground for judgement" [17], whereas the Holy Spirit endows the heart with the gift of the virtues and with the heat of divine love.

The Embodiment of the Logos created the teandric and Eucharistic realism, by His embodiment in man. The Logos lifted man to an overwhelming dignity. God created Adam neither immortal, nor mortal, but able of both situations, endowed with the power to want and to be able of everything, namely of good and of evil. Since Adam to this day, nobody has been saved by the power of nature, but by the grace of the Holy Spirit, in faith in the name of Jesus, "for there is no other name under heaven given among men by which we must be saved" (Acts 4:12) than the name of Jesus Christ [18].

The decisive arm of man is his freedom. Man has a unique freedom of will, not so much as a unique hypostasis, but of a unique nature. The will of man or of the human nature can only derive, therefore, from his divine nature. The Man-God contains in Himself each individual. Each man is virtually a true brother of Jesus Christ, a moment of the creature participating to the universal or symphonic personality of Jesus Christ. Only in Christ and with Christ does man acquire a personality. "Man is per se impersonal; each man is a virtual Christ".

The human nature is the participation to the Logos, and life is a becoming towards Christ. It is by the Logos that the multitude of things was made, the Logos is throughout everything because "they who have the Spirit of God are led to the Word, namely to the Son and the Son takes them and offers them to the Father and the Father gives to them the unrottenness (incorruptibility)" [19].

The Logos was sent by God to the people, as a king sends his son, a king for men, to save them by conviction. By the embodiment, "the Logos recapitulated in Him the whole human nature". As the first Adam was born out of the earth by the Logos of God, it was proper for this Logos, He Himself recapitulating Adam, to be born as well like Adam. "When the fullness of time had come, the Word made Himself a man, to recapitulate everything in Himself."

When the Word takes on the human nature, He established the communion between God and mankind. The Logos introduced God to the people in order for them to have Who to progress to.

"Christ's presence in the creation, by the power of the Spirit, is the only means by which the world was opened and by which it can open itself again to God" [20].

Man is treasured and lifted, he is "God's image" [21], equal in honour, rights and duties with all his fellows. Man is meant to grow up to the full measure of Christ's stature; man is a social Being, therefore he cannot live in isolation, but in community with the others.

The rationality of the cosmos reveals itself as a spiritual ground impressed on the creation by the Father, through the Son, in the Holy Spirit. Man is the Son's image and consequently he is "in the image of the Father". As an image of God's Word, the man subject of the things or co-subject together with his fellows, having the responsibility to see in things their divine reasons and, by them, the Logos itself as their supreme subject, is 
meant to develop the communion with his fellows, as together-subjects of the things, according to the image of the divine Logos.

\section{The man without Christ}

Today everybody agrees that life is becoming increasingly unbearable, the world increasingly insecure, that happiness is, in our age, an illusion. As a contemporary Orthodox hierarch says, "The tragic character of man and the feeling of his contradictory nature are increasingly intensely highlighted by the historical events" [22]. Because evil is no longer a particular, isolated and unextended reality, but, given the present technique, it is rapidly becoming the universal reality, influencing the history of the planet. For man there is no other solution but the return to Christ, because, since the Embodiment of the Logos, man is related by his very destiny to Christ. Jesus Christ's coming in the world or the Embodiment of God's Son brings in the world not a Law and a Reason, but the Law and the Reason, not some conception on life, but the supreme conception on life. "In Jesus Christ the measure of all things and of all the values in this world is revealed to us. Just as He is the centre of time, starting from Whom we count the years towards the world's beginning and towards the world's end, similarly He is the measure to which we refer the levels of life reached by Him or after Him.” [23].

Man's separation from God as a consequence of the modern and postmodern thinking determined man to consider himself "the measure of all things" and adopt a conception of life that does not correspond either to his earthly destiny or to the high aspirations for which he has been created. In this free choice lies the origin of the drama of the contemporary man and society.

Saint Seraphim of Sarov observes that "there are, today, at the limit, only two alternatives for man, absolutely irreconcilable: faith in the world and in the religion of the self, whose fruit is death; and faith in Christ, God's Son, the Only One in Whom there is Eternal Life".

At present, man is in a state of crisis and he must return to his natural state. And man's natural state is the one defining him as truly man; the man who is truly man is the man of virtue, the virtuous man, settled in good, the one who demonstrates strength in the opposition to sin and in whose life one can see the presence of Christ by behaviour and attitude. Man's natural state consists in the preoccupation for the superior, spiritual things, in taking on the responsibility for himself and for his fellows, in the cultivation and the affirmation of man's personal dignity. Man's natural state is precisely the state of grace, and he can only have this if he is in communion with Jesus Christ-God and with his fellows.

For the Christian, the ideal accomplishment in Christ consists in attaining "to mature adulthood, to the measure of the stature of the fullness of Christ" (Ephesians 4:13)

\section{Conclusions}

Man is made in the image of God so that, having a soul related to God out of the principle of life produced in man by the breath of God, he tends to God and is in a living relation with God. And by this relation of life, man maintains undiminished his kinship with God. The relation between man and God is possible due to the fact that God made man even since the beginning related to Himself. Making man in His image, God put man even since the beginning in an aware and free relation with Himself.

Moses' expressions about God's work in man's creation wonderfully highlight the difference between the types of works manifested by the Creator "because, describing the creation, the great prophet observed that all the other creatures were produced by God by the word", but He made man with His own hands. Man was brought into existence after all the 
creatures because he represents the being that makes the creation perfect and because he unites in Himself the material world with the spiritual world.

The divine-human person of Christ shows to us as obviously as possible that man was not created for autonomy, but for the communication with God. In His quality of true God and true Man, He constitutes the connecting link between the cosmos and the Trinity, by which the Spirit descends in the world, for the world to ascend towards communion with the heavenly Father.

\section{Bibliographic references:}

[1] Vladimir Lossky, Teologia mistica a Bisericii de Răsărit (The Mystical Theology of the Eastern Church), Edit. Bonifaciu, 1998.

[2] Panayotis Nellas, Omul - animal îndumnezeit (Zoon Theouumenon), Edit. Deisis, 1998, p. 65.

[3] Apud P.S. Irineu Slătineanul, Iisus Hristos sau Logosul inomenit (Jesus Christ or the Humanized Logos), Edit. România creştină, 1998, p. 6.

[4] Fr. Assoc. Prof. Dr. Vasile Citiriga, Taina omului si tragedia lui in epoca postmoderna (Man's Mystery and His Tragedy in the Postmodern Epoch), in "Ortodoxia", year LVII, no. 3-4, Jul.-Dec., 2006, Bucuresti, p.27.

[5] Fr. Prof. Dumitru Staniloae, Iisus Hristos, lumina lumii și îndumnezeitorul omului (Jesus Christ, the Light of the World and Man's Deifier), Ed. Anastasia, Bucuresti, 1993, p. 31-32.

[6] Mihai D. Vasile, Traditia simbolica a logosului crestin (The Symbolical Tradition of the Christian Logos), Ed. Punct, Bucuresti, 2000, p56.

[7] John Meyendorff, Sfântul Grigorie Palamas și mistica ortodoxă (Saint Gregory Palamas and the Orthodox Mysticism), translated by Angela Pagu, Ed. Enciclopedică, București, 1995, p.140-141.

[8] Apud Fr. Prof. D. Radu, Mântuirea, a doua creaţie a lumii (Salvation, the world's second creation), in Ortodoxia, XXXVI-II (1986), nr.2, p.47.

[9] Cf. Pavel Florensky, Stâlpul și Temelia Adevărului (The Pillar and Ground of the Truth), translated by Emil Iordache, Fr. Iulian Friptu and Fr. Dimitrie Popescu, Ed. Polirom, Iași, 1999, p.191.

[10]Fr. Prof. D. Popescu, Știinţa în contextul teologiei răsăritene și al celei apusene (Science in the Context of Eastern and Western Theology), in vol. Știinţă și teologie (Science and Theology), București, 2001, p.19.

[11] Note 449, in col. P.S.B., vol. 39, IBMBOR, București, 1992, p. 262.

[12] Vladimir Lossky, op.cit., p. 87.

[13] Fr. Prof. Dr. Dumitru Staniloae, Teologia Dogmatică Ortodoxă (Orthodox Dogmatic Theology), Edit. I.B.M.B.O.R., vol. 2, Bucureşti 1997, p 49.

[14] Panayotis Nellas, op. cit., p. 70.

[15] Ibidem, p. 75.

[16]Fr. Prof. Dr. I. G. Coman. Elemente de antropologie (Elements of Anthropology), in "Studii Teologice", year XX, no.3/1968, p. 64.

[17]Fr. Prof. Dr. Dumitru Radu, Îndrumări misionare (Missionary Guidelines), I.B.M.B.O.R., Bucureşti 1986, p. 179.

[18]Fr. Prof. Dr. I. G Coman, Şi cuvântul trup S-a făcut (And the Word Made Himself a Man), Edit. Mitropoliei Banatului şi Timişoarei, 1993, p. 43.

[19] His Beatitude Irineu Bistriţeanul, Sfântul Irineu de Lyon (Saint Irenaeus of Lyon), Edit. Cartimpex, Cluj-Napoca 1998, p. 48.

[20]Fr. Prof. Dr. Dumitru Popescu, Hristos-Biserica-Societate (Christ-Church-Society), Edit. I.B.M.B.O.R., Bucureşti 1998, p. 19

[21] Fr. Prof. Dr. I. G. Coman, Actualitatea gândirii patristice (The Topicality of the Patristic Thinking), in "Studii Teologice", Mitropolia Olteniei, year XXVII, no. 9-10/1975, p. 87.

[22] Serafim Rose, Mai aproape de Dumnezeu (Closer to God), Ed. Egumeniţa, Galati, 2003, p.35.

[23] Nichifor Crainic, Ortodoxie și etnocrație (Orthodoxy and Ethnocracy), Ed. Albatros, Bucuresti, 1997, p.36. 